\title{
Aktivitas Antioksidan dan Antibakteri Ekstrak Daun Pometia pinnata
}

Penulis

Afiliasi
Harlinda Kuspradini*, Whicliffe Fiernaleonardo Pasedan, Irawan Wijaya Kusuma

Fakultas Kehutanan Universitas Mulawarman

\section{Kata Kunci \\ - Pometia pinnata \\ - Antioksidan \\ $\curvearrowright$ DPPH \\ - Antibakteri \\ $\rightarrow$ 2, 3, 5-triphenyl tetrazolium chloride (TTC)}

Diterima 21 Agustus 2015

Direvisi 5 November 2015

Disetujui 24 Februari 2016

*Penulis korespondensi Harlinda Kuspradini

Fakultas Kehutanan Universitas Mulawarman

Jl. Ki Hajar Dewantara Kampus Gunung Kelua Samarinda. 75117. Kalimantan Timur alinkuspra@gmail.com

\section{Abstrak}

Penelitian ini bertujuan menentukan aktivitas antioksidan dan antibakteri berbagai jenis ekstrak daun Pometia pinnata. Kegiatan yang dilakukan meliputi proses ekstraksi daun Pometia pinnata dari Kalimantan Timur dengan teknik maserasi bertingkat menggunakan 3 pelarut: $n$-heksana, etil asetat, dan etanol. Ekstrak tersebut kemudian dievaluasi aktivitas antioksidan dan antimikrobanya.

Dari hasil penelitian menunjukkan bahwa ekstrak daun $P$. pinnata mengandung alkaloid, tannin, dan kumarin. Hasil pengujian antioksidan dengan metode peredaman radikal bebas DPPH, pada konsentrasi 100 ppm menunjukkan aktivitas antioksidan yang tinggi dengan nilai $89,23 \%, 89,23 \%$ dan $90,38 \%$ pada masing-masing ekstrak $n$-heksana, etil asetat dan etanol. Nilai antioksidan menunjukkan nilai yang hampir sama dengan antioksidan vitamin C sebesar 96 pada konsentrasi 25. Hasil pengujian antimikroba dengan metode pewarnaan 2, 3, 5-triphenyl tetrazolium chloride (TTC) menunjukkan bahwa ekstrak daun $P$. pinnata memiliki kemampuan yang cukup kuat dalam menghambat pertumbuhan bakteri Streptococcus mutans, Streptococcus sobrinus, Escherichia coli kecuali terhadap Propionibacterium acne.

\section{Pendahuluan}

Indonesia yang terletak di daerah tropis memiliki keunikan dan kekayaan hayati yang sangat luar biasa. Tercatat tidak kurang dari 30.000 jenis tanaman obat yang tumbuh di Indonesia walaupun yang sudah tercatat sebagai produk fitofarmaka (bisa diresepkan) baru terdapat sebanyak 5 produk dan obat herbal terstandar tercatat sebanyak 28 produk (Kurdi 2010). Tanaman dari famili Sapindaceae banyak tersebar di wilayah Indonesia dan di antara sudah digunakan sejak dulu oleh masyarakat lokal sebagai tanaman kebutuhan sehari - hari dan obat tradisional. Dari penelitian yang sudah dilakukan, beberapa jenis tanaman dari famili Sapindaceae memiliki potensi untuk dijadikan obat, antara lain Lepisanthes amoena, Cardiospermum Halicacabum, 
Paullinia pinnata, Nephelium lappaceum, Cardiospermum canescens (Thitilertdecha, et al 2010; Kuspradini et al. 2012; Rajasekaran et al. 2013; Udhayasankar et al. 2013; Lunga et al. 2014). P. pinnata atau dikenal dengan Matoa merupakan jenis tanaman famili Sapindaceae yang tersebar di wilayah Asia Tenggara (Malaysia dan Indonesia) dan dimanfaatkan oleh masyarakat sebagai obat - obatan tradisional dan buahnya dapat dimakan. Penyebarannya di wilayah Indonesia meliputi daerah Sumatra, Jawa, Kalimantan, Sulawesi, P.Sumbawa (NTB), dan Maluku (Sudarmono 2000). Beberapa hasil penelitian sebelumnya yang mengatakan bahwa ekstrak daun $P$. pinnata mampu menghambat virus HIV-1 IN (Suedee 2012) dan kulit batangnya memiliki aktivitas inhibitor $\alpha$-glukosidase (Mataputun et al. 2013). Buah tumbuhan Matoa juga sudah sangat terkenal memiliki khasiat sebagai antioksidan, namun bagian lain dari tumbuhan ini belum diketahui aktivitas antioksidannya.

Penelitian ini bertujuan untuk menentukan aktivitas antioksidan dan antimikroba daun tanaman $P$. pinnata yang diekstraksi dengan cara metode maserasi bertingkat menggunakan pelarut $n$-heksana, etil asetat dan etanol. Pengukuran aktivitas antioksidan dilakukan menggunakan metode peredaman radikal bebas DPPH dan antimikroba terhadap 4 jenis bakteri (Propionibacterium acnes, Streptococus mutans, Streptococcus sobrinus, dan Escherichia coli).

Diharapkan dari penelitian ini dapat memberikan informasi mengenai potensi antioksidan dan antibakteri serta sebagai salah satu referensi/ perbandingan untuk penelitian lebih lanjut.

\section{Metode Penelitian}

Penelitian ini dilakukan di Laboratorium Kimia Hasil Hutan Fakultas Kehutanan Universitas Mulawarman. Proses awal pembuatan ekstrak adalah penyiapan serbuk simplisia kering. Sampel daun yang digunakan dibersihkan dari kotoran lalu dikeringkan dalam ruangan dengan suhu konstan. Setelah kering, semua daun diblender hingga menjadi serbuk.

Pengukuran faktor kelembaban dilakukan dengan menggunakan standar TAPPI T264 om-88. Pengukuran faktor kelembapan dilakukan untuk mendapatkan berat sampel kering oven dari sampel daun yang digunakan dalam pengujian. Untuk mencari faktor kelembaban digunakan rumus berikut:

$$
\text { Faktor Kelembaban }=\frac{\text { Berat Kering Oven }(g)}{\text { Berat Mula }- \text { mula }(g)}
$$

Proses ekstraksi menggunakan metode maserasi suksesif atau ekstraksi bertingkat. Pada proses awal, sampel direndam menggunakan pelarut $n$-heksana. Residu dari $n$-heksana kemudian dimaserasi kembali dengan menggunakan pelarut etil asetat. Pada akhir dari proses maserasi, residu dari etil asetat direndam menggunakan pelarut etanol. Semua kegiatan perendaman sampel dilakukan pengadukan shaker selama 2 × 24 jam pada suhu kamar. Selanjutnya larutan disaring dan dipekatkan menggunakan rotary vacuum evaporator sehingga didapatkan ekstrak kasar pada setiap pelarut.

Analisis fitokimia dilakukan terhadap ekstrak $n$ heksana, etil asetat, dan etanol dari 4 jenis tanaman famili Sapindaceae. Analisis fitokimia yang dilakukan meliputi uji perubahan warna yang mengacu pada Harborne (1987), Kokate (2001), dan Senthilmurugan et al. (2013) untuk menguji adanya senyawa aktif, antara lain:

1. Uji alkaloid (Kokate 2001). Sebanyak $5 \mathrm{ml}$ ekstrak ditambahkan $2 \mathrm{ml} \mathrm{HCl}$, kemudian dimasukkan 1 $\mathrm{ml}$ larutan Dragendorff. Perubahan warna larutan menjadi jingga atau merah mengindikasikan bahwa ekstrak mengandung alkaloid.

2. Uji flavonoid (Senthilmurugan et al. 2013). $1 \mathrm{ml}$ ekstrak direbus dengan $5 \mathrm{ml}$ air aquades selama 5 menit, kemudian disaring lalu diukur sebanyak $1 \mathrm{ml}$ filtrat dan ditambahkan beberapa tetes larutan natrium hidroksida $20 \%$, jika pada saat penambahan terbentuk warna kuning maka filtrat tersebut mengandung flavonoid.

3. Uji Triterpenoid dan Steroid (Harborne 1987). Identifikasi dilakukan dengan menggunakan campuran asam asetat anhidrida dan asam sulfat pekat yang biasa dikenal dengan pereaksi Liebermann-Burchard. Pada pengujian ini 10 tetes asam asetat anhidrida dan 2 tetes asam sulfat pekat ditambahkan secara berurutan 
ke dalam $1 \mathrm{ml}$ sampel uji yang telah dilarutkan dalam aseton. Selanjutnya sampel uji dikocok dan dibiarkan beberapa menit. Reaksi yang terjadi diikuti dengan perubahan warna, apabila terlihat warna merah dan biru maka uji dinyatakan positif adanya steroid.

4. Uji tanin (Kokate 2001). Pengujian dilakukan dengan memasukkan $10 \mathrm{ml}$ larutan ekstrak ke dalam tabung reaksi dan ditambahkan larutan timbal asetat $\left(\mathrm{CH}_{3} \mathrm{COO}\right)_{2} \mathrm{~Pb} 1 \%$. Tanin dinyatakan positif apabila pada reaksi terbentuk endapan kuning.

5. Uji saponin (Harborne 1987). Pengujian dilakukan dengan menimbang sampel uji $60 \mathrm{mg}$ pada tabung reaksi kemudian dilarutkan aseton sebanyak $2 \mathrm{ml}$, lalu ditambahkan air panas $3 \mathrm{ml}$. Selanjutnya larutan didinginkan dan dikocok selama 10 detik. Terbentuknya buih mantap selama kurang lebih 10 menit dengan ketinggian 1-10 cm dan tidak hilang bila ditambahkan 1 tetes $\mathrm{HCl} 2 \mathrm{~N}$ menandakan bahwa ekstrak yang diuji mengandung saponin.

6. Uji karotenoid (Senthilmurugan et al. 2013), sebanyak $1 \mathrm{ml}$ ekstrak dicampur dengan $5 \mathrm{ml}$ kloroform dalam tabung reaksi, kemudian dikocok lalu disaring kemudian ditambahkan asam sulfat $85 \%$. Jika terbentuk warna biru di atas permukaan maka menunjukkan adanya karotenoid.

7. Uji Kumarin (Senthilmurugan et al. 2013). Sebanyak $1 \mathrm{ml}$ larutan ekstrak dicampur dengan beberapa tetes $\mathrm{NaOH}$ kemudian ditambahkan alkohol jika terbentuk warna kuning maka menunjukkan adanya kumarin.

Metode uji antioksidan yang digunakan berdasarkan metode Shimizu et al. (2001). Uji dilakukan dengan menggunakan UV/VIS 1200 spektrofotometer dengan temperatur $25{ }^{\circ} \mathrm{C}$. Disiapkan tabung reaksi kemudian sebanyak $33 \mu \mathrm{l}$ ekstrak daun yang telah dilarutkan dalam DMSO dimasukkan dalam tabung, ditambahkan $467 \mu \mathrm{l}$ etanol, lalu dihomogenkan antara pelarut dan sampel, kemudian ditambahkan $500 \mu \mathrm{L}$ DPPH (konsentrasi 0,0027\% pada pelarut etanol) setelah itu diinkubasi selama 20 menit dalam suhu ruang tanpa cahaya. Sampel yang telah diinkubasi dimasukkan ke dalam cuvette untuk melakukan perhitungan peredaman DPPH menggunakan spektrofotometer. Aktivitas antioksidan dapat ditentukan melalui dekolorisasi dari DPPH pada panjang gelombang $514 \mathrm{~nm}$.

$$
\% \text { Peredaman }=\frac{A B S \text { kontrol }(-)-A B S \text { sampel }}{A B S \text { kontrol }(-)} \times 100 \%
$$

Dimana:

- $\quad A B S$ control = Nilai absorbansi tanpa ekstrak

- $\quad A B S$ sampel = Nilai absorbansi dengan ekstrak

Pengujian Antibakteri dilakukan dengan metode pewarnaan menggunakan 2, 3, 5-triphenyl tetrazolium chloride (TTC). Bakteri yang digunakan adalah P. acnes, S. mutans, S. sobrinus, dan E.coli.

Sebelum dilakukan pengujian antibakteri, dipersiapkan sampel uji dengan membuat stok sampel uji. Sampel uji ditimbang sebanyak $5 \mathrm{mg}$, kemudian ditambahkan etanol $40 \%$ sebanyak $1 \mathrm{~mL}$ untuk membuat stok dengan konsentrasi sebesar 5000 ppm.

Media bakteri yang digunakan dalam pengujian ini adalah media cair dan padat. Sebanyak 8 gram nutrient broth, 10 gram glukosa, dan 20 gram agar dimasukkan ke dalam $1000 \mathrm{ml}$ akuades dan dididihkan sampai melarut sempurna, lalu dimasukkan ke dalam gelas piala untuk disterilisasi dengan autoclave pada suhu $121^{\circ} \mathrm{C}$ selama 20 menit (Thiel, 1999).

Bakteri yang digunakan dalam pengujian ini adalah $P$. acnes, S. mutans, S. sobrinus, dan E. coli. Bakteri dimasukkan ke dalam akuades lalu dihomogenkan. Bakteri yang digunakan disesuaikan dengan standar Mc. Farland skala 0,5 atau pada transmitan $74 \%$ dengan panjang gelombang $600 \mathrm{~nm}$ (Prolab Diagnostics 2012)

Metode uji antibakteri yang digunakan berdasarkan metode Elkhair et al. (2010) yang sudah dimodifikasi. Stok sampel dimasukkan ke dalam microplate 96 wells sebanyak $50 \mu \mathrm{l}$ dan dilakukan pengenceran dengan hasil konsentrasi akhir pada well 1250 - $312.5 \mu \mathrm{g} / \mathrm{ml}$. Kemudian ditambahkan media cair nutrient broth sebanyak $100 \mu \mathrm{l}$ dan $50 \mu \mathrm{l}$ larutan bakteri yang telah disuspensi dengan akuades. Microplate yang telah diinokulasi dengan bakteri diinkubasi selama 24 jam pada incubator dengan suhu $37^{\circ} \mathrm{C}$. Satu jam sebelum proses inkubasi selesai, ditambahkan $50 \mu \mathrm{l}$ larutan 2, 3, 5-triphenyl tetrazolium chloride (TTC). Proses akhir dari 
pengujian ini adalah timbulnya warna merah yang mengindikasikan masih hidupnya bakteri yang diuji ke masing-masing sampel. Konsentrasi Hambat Minimum (KHM) dilihat dari well pertama yang tidak berwarna merah.

Setelah mengetahui KHM dari sampel uji, Selanjutnya dilakukan pengujian antimikroba untuk mengetahui konsentrasi bunuh minimum (KBM) dari sampel uji. Dimasukkan sebanyak $20 \mathrm{ml}$ media padat ke dalam cawan petri. Kemudian dimasukkan sampel yang sudah diketahui KHM-nya ke dalam media padat dengan metode streak plate. Kemudian diinkubasi selama 18 jam. Proses akhir dari pengujian ini adalah tumbuh tidaknya bakteri yang sudah diketahui KHM untuk mengetahui sampel uji memiliki daya bunuh terhadap bakteri.

\section{Hasil dan pembahasan}

Metode ekstraksi yang digunakan adalah maserasi bertingkat (non polar - polar) menggunakan pelarut $n$-heksana, etil asetat dan etanol. Hal ini bertujuan agar zat aktif yang ada dalam sampel bisa diekstraksi secara maksimal. Selain itu perbedaan pelarut yang digunakan bertujuan untuk mengekstraksi zat aktif yang berbeda polaritasnya sehingga bisa diekstraksi dengan baik. Serbuk direndam selama $2 \times 24$ jam kemudian dipekatkan hingga diperoleh ekstrak kasar.

Hasil ekstraksi dari daun $P$. pinnata menunjukkan nilai rendemen tertinggi sebesar $12.26 \%$ dengan menggunakan pelarut etanol. Sementara itu untuk rendemen terendah terdapat pada ekstrak $n$-heksana dengan nilai rendemen $0,99 \%$. Maserasi menggunakan pelarut etanol dinilai lebih menguntungkan karena sifat etanol yang mudah melarutkan senyawa yang bersifat non-polar, semi-polar dan polar (Arifin et al. 2006). Hal inilah yang menyebabkan rendemen tertinggi ekstrak ada pada pelarut etanol.

Metabolit sekunder adalah senyawa kimia yang umumnya mempunyai kemampuan bioaktivitas dan berfungsi sebagai pelindung tumbuhan tersebut dari gangguan, misalnya gangguan hama. Senyawa metabolit sekunder telah banyak digunakan sebagai zat warna, racun, aroma makanan, obat-obatan dan sebagainya serta sangat banyak jenis tumbuhtumbuhan yang digunakan obat-obatan yang dikenal sebagai obat tradisional sehingga diperlukan penelitian tentang penggunaan tumbuh-tumbuhan berkhasiat dan mengetahui senyawa kimia yang berfungsi sebagai obat. Identifikasi kandungan metabolit sekunder merupakan langkah awal yang penting dalam penelitian pencarian senyawa bioaktif baru dari bahan alam yang dapat menjadi prekursor bagi sintesis obat baru atau prototipe obat beraktivitas tertentu (Rasyid 2012).

Seluruh ekstrak daun $P$ pinnata mengandung alkaloid. Tanaman famili Sapindaceae salah satu kategori tumbuhan berbuah yang memiliki rasa pahit pada bagian daun. Hal ini diduga terkait dengan adanya kandungan alkaloid pada tumbuhan famili Sapindaceae. Astarina et al. (2013) mengatakan bahwa hampir seluruh alkaloid berasal dari tumbuhan dan ditemukan dalam berbagai bagian

Tabel 1. Rendemen Ekstrak dengan Pelarut $n$-Heksana, Etil asetat dan Etanol

\begin{tabular}{cccccc}
\hline No & Pelarut & Berat Sampel Awal (gram) & FK* & Berat Ekstrak (gram) & Rendemen (\%) \\
\hline 1 & n-heksana & 180.12 & 0.86 & 1.78 & 0.99 \\
2 & Etil Asetat & 180.12 & 0.86 & 5.18 & 2.88 \\
3 & Etanol & 180.12 & 0.86 & 22.09 & 12.26 \\
\hline
\end{tabular}

*FK = Faktor Kelembaban

Tabel 2. Kandungan Fitokimia Ekstrak Daun P. pinnata

\begin{tabular}{llccccccccc}
\hline \multirow{2}{*}{ No } & \multirow{2}{*}{ Ekstrak dengan pelarut pengekstraksi } & \multicolumn{7}{c}{ Fitokimia } \\
\cline { 3 - 8 } & N - Heksana & + & + & + & + & - & - & - & + \\
\hline 1 & Etil Asetat & + & + & - & + & - & + & - & + \\
3 & Etanol & + & + & + & + & + & - & - & + \\
\hline
\end{tabular}

Ket: Alk: Alkaloid; Flav: Flavonoid; Terp: Terpenoid; Sap: Saponin; Ster: Steroid; Krt: Karotenoid; Kum: Kumarin: + : Ada. - : Tidak ada 
tanaman.

Menurut Aniszewki (2007), alkaloid merupakan senyawa yang memiliki aktivitas antimikroba. yaitu menghambat esterase dan juga DNA dan RNA polimerase. juga menghambat respirasi sel dan berperan dalam interkalasi DNA. Selain itu. alkaloid adalah senyawa kimia organik yang mengandung nitrogen heterosiklik dan kebanyakan dari senyawa ini bersifat toksik/beracun serta tidak memiliki bau yang sedap. Alkaloid dapat meningkatkan serapan nutrisi dan melancarkan peredaran darah. mengurangi rasa sakit dan menstimulasi sistem syaraf. Senyawa alkaloid juga dapat digunakan sebagai anti bakteri dan anti jamur (Rizwana et al. 2010).

Flavonoid merupakan grup fenolik yang tersebar secara luas di dalam tumbuhan. berpotensi dan memiliki aktivitas anti - kanker yang tinggi. Flavonoid juga telah terbukti diketahui sebagai senyawa dengan efek farmakologi yang cukup tinggi misalnya sebagai antibakteri. antioksidan. antiinflamasi dan anti jamur pada salah satu metabolit sekundernya (Mbadianya et al.. 2013; Rahimah et al.. 2013).

Disebutkan dalam Harborne (1987) bahwa tannin terdapat luas dalam tumbuhan berpembuluh. sedangkan dalam angiospermae terdapat dalam jaringan kayu. Tannin yang terdapat dalam tanaman biasanya dipakai sebagai pewarna alami. Kebutuhan pewarna alami dipenuhi dari beberapa tanaman diantaranya adalah: alpukat (Parsea america mill). cengkeh (Eugenia aromatica). jambu (Jambosa densiflora). kunyit (Curcuma domestica). srikaya (Annona squamosa). delima (Punica granatum) dan lain sebagainya (Martono et al. 2012).Pada pengujian saponin. hanya pada ekstrak etanol daun $P$. pinnata saja yang positif saponin. Dalam Padmasari et al (2013) menyebutkan saponin merupakan metabolit sekunder yang sangat familiar untuk proses glikolisis dan merupakan senyawa aktif permukaan yang dapat menimbulkan busa jika dikocok dalam air. $\mathrm{Hal}$ tersebut terjadi karena saponin memiliki gugus polar dan non polar yang akan membentuk misel pada saat misel terbentuk maka gugus polar akan menghadap keluar dan gugus non polar akan menghadap ke dalam. Keadaan inilah yang akan tampak seperti busa. Selain itu juga karena gugus polar menghadap keluar. hal ini menyebabkan senyawa saponin mudah ekstraksi di pelarut yang bersifat polar seperti etanol. Rizwana et al. (2010) juga melaporkan bahwa senyawa ini dipercaya dapat mengkontrol kolesterol pada proses diet. dan juga digunakan sebagai obat beberapa penyakit kulit (seperti ruam). Saponin juga bisa digunakan sebagai anti - inflamasi serta digunakan untuk proses penyembuhan pada penyakit tuberkolosis.

Senyawa triterpenoid biasanya mudah diisolasi jika terbentuk minyak atsiri. Hal ini sejalan dengan pendapat Lenny (2006) yang menyebutkan bahwa triterpenoid adalah komponen - komponen tumbuhan yang mempunyai bau dan dapat diisolasi dari bahan nabati dengan penyulingan disebut sebagai minyak atsiri. Dalam Mbadianya et al. (2013) melaporkan bahwa steroid adalah senyawa yang memiliki aktivitas antibakteri dan merupakan senyawa yang memiliki peranan penting dalam perkembangan hormon.

Pada pengujian kandungan karotenoid. semua ekstrak tidak menunjukkan adanya kandungan senyawa karotenoid. Berbeda dengan karoteniod. semua ekstrak daun $P$ pinnata mengandungg kumarin. Isnawati et al. (2008) melaporkan bahwa kumarin memiliki aktivitas biologis diantaranya dapat menstimulasi pembentukan pigmen kulit, mempengaruhi kerja enzim, anti-koagulan darah, antimikroba dan menunjukkan aktivitas menghambat efek karsinogen. Selain itu senyawa turunan kumarin polisiklik aktif sebagai anti karsinogen yang disebabkan hidrokarbon aromatik polisiklik karsinogen seperti 6 - metil $(\alpha)$ piran.

Dalam pengujian antioksidan masing-masing ekstrak digunakan spektrofotometer UV-Vis untuk melihat serapan DPPH pada panjang gelombang 514 $\mathrm{nm}$. Pengujian yang dilakukan menggunakan asam askorbat (Vitamin C) sebagai kontrol positif. Pengujian antioksidan menggunakan 3 jenis pelarut dengan konsentrasi berturut - turut adalah 100 ppm. 50 ppm dan 25 ppm. Adapun hasil dari masing masing pengujian yang telah dilakukan dapat dilihat pada Tabel 3. Diantara ketiga ekstrak yang diuji. ekstrak etanol $P$. pinnata memperlihatkan nilai persen peredaman DPPH yang paling tinggi. Nilai aktivitas tertinggi diperoleh pada ekstrak etanol dengan konsentrasi 100 ppm dengan nilai $90.38 \%$. 
Tabel 3. Peredaman Radikal Bebas DPPH dari Ekstrak Daun P. pinnata

\begin{tabular}{ccccc}
\hline \multirow{2}{*}{ Sampel } & \multirow{2}{*}{ Konsentrasi $(\mu \mathrm{g} / \mathrm{mL})$} & \multicolumn{2}{c}{ Absorban } & \multirow{2}{*}{ \% Peredaman DPPH } \\
\cline { 3 - 4 } Vitamin C & 100 & DMSO (-) & Sampel uji & \\
\hline \multirow{3}{*}{ Ekstrak $n$-Heksana } & 50 & 0.378 & 0.005 & $98.59 \pm 0.004$ \\
& 25 & & 0.004 & $98.85 \pm 0.002$ \\
& 100 & 0.378 & 0.012 & $96.73 \pm 0.004$ \\
\hline \multirow{3}{*}{ Ekstrak Etil Asetat } & 50 & & 0.233 & $60.81 \pm 0.028$ \\
& 25 & & 0.288 & $38.39 \pm 0.014$ \\
& 100 & 0.378 & 0.115 & $23.74 \pm 0.022$ \\
\hline \multirow{2}{*}{ Ekstrak Etanol } & 50 & & 0.112 & $69.55 \pm 0.010$ \\
& 25 & 0.378 & 0.144 & $70.34 \pm 0.027$ \\
& 100 & & 0.036 & $61.96 \pm 0.003$ \\
\hline
\end{tabular}

Dalam Yuhernita et al. (2011) menjelaskan bahwa radikal bebas dikenal sebagai faktor utama dalam kerusakan biologis. dan DPPH digunakan untuk mengevaluasi aktivitas peredaman radikal bebas dari suatu antioksidan alami. DPPH yang merupakan suatu molekul radikal bebas dengan warna ungu dapat berubah menjadi senyawa yang stabil dengan warna kuning oleh reaksi dengan antioksidan. dimana antioksidan memberikan satu elektronnya pada DPPH sehingga terjadi peredaman radikal bebas DPPH. Uji DPPH merupakan metode yang mudah untuk menapis sejumlah molekul antioksidan karena reaksi dapat diamati secara visual. dan juga bisa dihitung intensitasnya menggunakan spektofotometri sederhana. P. pinnata mengandung flavonoid. tannin. dan saponin. Hal ini sejalan dengan pendapat Rahimah et al. (2013) yang menyebutkan bahwa daun $P$. pinnata diketahui mengandung senyawa kimia berupa flavonoid. tannin. dan saponin. Ditambahkannya pula bahwa senyawa flavonoid yang telah diisolasi merupakan golongan auron dengan $\mathrm{Rf}$ $=0.51$.

Selain itu. ditemukan juga adanya senyawa yang mengarah pada golongan saponin dan tannin. Suedee (2012) yang menginvestigasi ekstrak daun $P$. pinnata dan $M$. elengi mendapatkan bahwa $P$. pinnata memiliki senyawa aktif proanthocyanidin A2 yang mampu menghambat virus HIV-1 IN dengan $\mathrm{IC}_{50}$ sebesar 30.1 MM. Adapun Mataputun et al (2013) juga melaporkan bahwa ekstrak etanol dari kulit batang $P$. pinnata memiliki aktivitas inhibitor $\alpha$ glukosidase berturut turut sebesar 19.56; 24.79 dan $100 \%$ pada konsentrasi 5; 12.5; 25; dan 50 ppm. Ekstrak kulit batang $P$. pinnata juga dapat menghambat pertumbuhan bakteri Staphylococcus aureus sebesar $14.61 \mathrm{~mm}$ (Ngajow et al. 2013). Dari hasil analisis fitokimia juga menunjukkan bahwa ekstrak etanol kulit batang matoa mengandung senyawa flavonoid. tannin. triterpena dan saponin.

Tabel 4 menunjukkan hasil yang diperoleh pada pengujian antibakteri untuk menentukan KHM dan KBM menggunakan metode dilusi dan difusi. Hasil yang didapat menunjukkan bahwa semua ekstrak dari berbagai pelarut menunjukkan nilai KHM yang sama $(312.5 \mu \mathrm{g} / \mathrm{mL})$ terhadap bakteri $S$. mutants. S. sobrinus. dan E. coli kecuali ekstrak nheksana. Nilai KHM pada bakteri $P$. acne menunjukan nilai yang sama dari berbagai ekstrak dengan nilai $1250 \mu \mathrm{g} / \mathrm{mL}$. Hasil KBM juga menunjukkan bahwa semua ekstrak membutuhkan konsentrasi lebih besar dari $1250 \mu \mathrm{g} / \mathrm{mL}$ untuk membunuh bakteri yang tumbuh. Salni et al (2011) mengungkapkan bahwa berdasarkan nilai KHM dan KBM yang dimilikinya. maka suatu ekstrak yang memiliki potensi antibakteri dapat dibedakan menjadi 4 (Tabel 5). Dilihat dari klasifikasi menurut Salni et al (2011). maka hampir 
Tabel 4. Konsentrasi Hambat dan Bunuh Minimum dari Ekstrak Daun P. pinnata

\begin{tabular}{|c|c|c|c|c|c|c|}
\hline \multirow{2}{*}{ No } & \multirow{2}{*}{ Pengukuran } & \multirow{2}{*}{ Ekstrak } & \multicolumn{4}{|c|}{ Bakteri } \\
\hline & & & S. mutans & S. sobrinus & P. acne & E. coli \\
\hline \multirow{4}{*}{1} & \multirow{4}{*}{$\mathrm{KHM}(\mu \mathrm{g} / \mathrm{ml})$} & n-Heksana & 1250 & 312.5 & 1250 & 312.5 \\
\hline & & Etil asetat & 312.5 & 312.5 & 1250 & 312.5 \\
\hline & & Etanol & 312.5 & 312.5 & 1250 & 312.5 \\
\hline & & Kontrol + & 312.5 & 312.5 & 312.5 & 312.5 \\
\hline \multirow{4}{*}{2} & \multirow{4}{*}{$\begin{array}{l}\text { KBM } \\
(\mu \mathrm{g} / \mathrm{ml})\end{array}$} & $n$-Heksana & $>1250$ & $>1250$ & $>1250$ & $>1250$ \\
\hline & & Etil asetat & $>1250$ & $>1250$ & $>1250$ & $>1250$ \\
\hline & & Etanol & $>1250$ & $>1250$ & $>1250$ & $>1250$ \\
\hline & & Kontrol + & 312.5 & 312.5 & 312.5 & 312.5 \\
\hline
\end{tabular}

Keterangan : KHM : Konsentrasi Hambat Minimum. KBM : Konsentrasi Bunuh Minimum

semua ekstrak yang diuji memiliki kemampuan cukup kuat dalam menghambat pertumbuhan bakteri $S$. mutan. S. sobrinus. dan E. coli. namun tidak ada aktivitas dalam menghambat pertumbuhan bakteri $P$. acne. Pemberian antibakteri dalam jumlah yang berlebihan dan secara terus-menerus akan menyebabkan sel bakteri menjadi resisten.

Pengujian yang dilakukan untuk mengetahui nilai KHM dari suatu sampel uji antibakteri sangat penting. karena selain bertujuan untuk meningkatkan efektivitas dari senyawa antibakteri tersebut juga bertujuan untuk mencegah timbulnya masalah resistensi bakteri karena penggunaan dosis yang berlebihan sehingga sel bakteri lama kelamaan akan menjadi kebal. Keberadaan metabolit sekunder menjadi faktor penting melalui mekanismenya terhadap bakteri mekanisme kerja tannin sebagai antibakteri adalah menghambat enzim reverse transcriptase dan DNA topoisomerase sehinnga sel bakteri tidak dapat terbentuk. tannin juga memiliki aktivitas antibakteri yang berhubungan dengan kemampuannya menginaktifkan enzim. dan mengganggu transport protein pada lapisan sel. Tannin juga mempunyai target pada polipeptida dinding sel sehingga pembentukan dinding sel menjadi tidak sempurna. sehingga hal ini menyebabkan bakteri menjadi lisis karena tekanan osmotik maupun fisik yang akan menyebabkan bakteri mati (Ngajow et al. 2013).

Senyawa terpenoid juga diketahui aktif melawan bakteri. tetapi mekanisme antibakterial triterpenoid masih belum benar - benar diketahui. Aktivitas antibakteri terpenoid diduga melibatkan pemecahan membran oleh komponen - komponen lipofilik. Selain itu. senyawa fenolik dan terpenoid memiliki target utama yaitu membran sitoplasma yang mengacu pada sifat alamnya yang hidrofobik (Ngajow et al. 2013).

Dari hasil penelitian. selain memiliki kandungan metabolit sekunder seperti alkaloid. tannin. dan kumarin; ekstrak n-heksana. etil asetat dan etanol dari daun $P$. pinnata dengan konsentrasi 100 ppm mengandung antioksidan yang tinggi dengan nilai yang hampir sama dengan antioksidan vitamin $\mathrm{C}$ pada konsentrasi 25 ppm. Aktivitas antimikroba juga ditunjukkan pada ketiga ekstrak tersebut dengan kemampuan yang cukup kuat melawan bakteri $S$. mutans. S. sobrinus. E. coli. Namun kurang mampu menghambat pertumbuhan $P$. acnes. Ekstrak nheksana juga tidak memiliki aktivitas dalam menghambat pertumbuhan bakteri $S$. mutans. Dengan demikian dapat diambil kesimpulan bahwa daun $P$. pinnata berpotensi dijadikan bahan dan diolah menjadi antioksidan dan antibakteri alami.

Tabel 5. Klasifikasi Penghambatan Bakteri (Salni et al 2011)

\begin{tabular}{ccc}
\hline No & Golongan & Keterangan \\
\hline 1 & $<100 \mu \mathrm{g} / \mathrm{mL}$ & Sangat kuat \\
2 & $100-500 \mu \mathrm{g} / \mathrm{mL}$ & Cukup kuat \\
3 & $500-1.000 \mu \mathrm{g} / \mathrm{mL}$ & Lemah \\
4 & $>1000 \mu \mathrm{g} / \mathrm{mL}$ & Tidak ada aktivitas \\
\hline
\end{tabular}

\section{Daftar Pustaka}

Aniszewki T. 2007. Alkaloid-secrets of life. Amsterdam: Elsevier. pp. 187

Arifin. Helmi. Aggraini. Nelvi. Handayani. Dian. Rasyid. Roslinda. 2006. Standarisasi Ekstrak Etanol 
daun Eugenia Cumini Merr. J. Sains Tek. Far. 11 (2).

Astarina NWG, Astuti KW, Warditiani NK. 2013. Skrining Fitokimia Ekstrak Metanol Rimpang Bangle Zingiber purpureum Roxb. Jurnal Farmasi Udayana.

Elkhair EA, Fadda H, Mohsen UA. 2010. Antibacterial Activity and Phytochemical Analysis of Some Medicinal Plants from Gaza Strip-Palestine. Journal of Al Azhar University.

Ganiswarna SG. 1995. Farmakologi dan Terapi. Ed 4. Jakarta : Fakultas Kedokteran UI.

Harborne JB. 1987. Metode Fitokimia: Penuntun Cara Modern Menganalisis Tumbuhan. Bandung. Penerbit ITB.

Holt JC. 1994. Bergey's Manual of Determinative Bacteriology. Edisi ke-9. Williams and Wilkins Company.

Isnawati A, Muhadar H, Kamilatunisah. 2008. Isolasi dan Identifikasi Senyawa Kumarin dari Tanaman Artemisia annua L. Artikel Media Litbang Kesehatan. Vol. 18 (3):107 - 118.

Kokate CK. 2001. Pharmacognosy. Edisi ke 16. Mumbai (IN) : Niali Prakasham.

Kurdi A. 2010. Tanaman Herbal Indonesia; Cara Mengolah dan Manfaatnya Bagi Kesehatan. Jakarta (ID): Rineka Cipta.

Kuspradini H, Susanto D, Ritmaleni, Mitsunaga T. 2012. Phytochemical and Comparative Study of Antimicrobial Activity of Lepisanthes amoena Leaves Extract. Journal of Biology Agriculture and Healthcare. 2 (11):80-86.

Lenny S. 2006. Senyawa Terpenoida dan Steroida. Karya IImiah. Fakultas Matematika dan IImu Pengetahuan Alam Universitas Sumatera Utara.

Lunga PK, Qin X, Yang XW, Kuiate JR, Du ZZ, Gatsing D. 2014. Antimicrobial steroidal saponin and oleanane - type triterpenoid saponins from Paullinia pinnata. BMC Complementary and Alternative Medicine. 14: 369.

Martono T, Haryono G, Gustinah D, Putra FA. 2012. Ekstraksi Tannin Sebagai Bahan Pewarna Alami dari Tanaman Putri Malu (Mimosa Pudica) Menggunakan Pelarut Organik. Reaktor. 14(1):39- 45 .

Mataputun SP, Rorong JA, Pontoh J. 2013. Aktivitas Inhibitor $\alpha$-Glukosidase Ekstrak Kulit Batang
Matoa (Pometia pinnata. Spp.) sebagai Agen Antihiperglikemik. Jurnal MIPA Unsrat Online. 2(2): $119-123$.

Mbadianya JI, Echezona BC, Ugwuoke KI, Wokocha RC. 2013. Phytochemical Constituens of Some Medicinal Plants. International Journal of Science and Research. 2(4):18 - 22.

Ngajow M, Abidjulu J, Kamu VS. 2013. Pengaruh Antibakteri Ekstrak Kulit Batang Matoa (Pometia pinnata) terhadap Bakteri Staphylococcus aureus secara in vitro. Jurnal MIPA UNSRAT online. 2(2):128 - 132.

Padmasari PD. Astuti KW, Warditiani NK. 2013. Skrining Fitokimia Ekstrak Etanol 70 \% Rimpang Bangle Zingiber purpureum Roxb. Jurnal Farmasi Udayana.

Prolab Diagnostics. 2012. McFarland Standards. Product Code SD2350. SD2300. SD2301. SD2302. SD2303. SD2304

Rahmi, Sayekti E, Jayuska A. 2013. Karakterisasi Senyawa Flavonoid Hasil Isolat dari Fraksi Etil Asetat Daun Matoa Pometia pinnata. J. R. Frost \& G. Frost. Jurnal Kimia Khatulistiwa. 2(2):8489.

Rajasekaran A, Kalaiselvan V, Sarathikumar N, Kalaivani M. 2013. Simultaneous Estimation of Luteolin and Apigenin in Methanolic Leaf Extract of Cardiospermum Halicacabum by HPLC. International Research Journal of Pharmacy. 4 (7):109-113

Rasyid A. 2012. Identifikasi Senyawa Metabolit Sekunder Serta Uji Aktivitas Antibakteri dan Antioksidan Ekstrak Metanol Teripang Stichopus hermanii. Jurnal IImu dan Teknologi Kelautan Tropis. 4(2):360 - 368.

Rina S. 2011. Formulasi Krim ekstrak Daun Pepaya (Carica papaya Linn) dan Madu sebagai Anti jerawat (Antiacne) yang diuji pada Bakteri. [Skripsi]. Bandung (ID): Universitas Islam Bandung.

Rizwana JN, Nazlina I, Razehar ARM, Noraziah AZS, Ling CY, Muzaimah SAS, Farina AH, Yaacob WA, Ahmad IB, Din LB. 2010. A Survey on Phytochemical and Bioactivity of Plant Extracts from Malaysian Forest Reserves. Journal of Medicinal Plants Research. 4(3):203 - 210.

Salni, Marisa H, Mukti RW. 2011. Isolasi Senyawa Antibakteri Dari Daun Jengkol Pithecolobium 
lobatum Benth dan Penentuan Nilai KHM-nya. Jurnal Penelitian Sains. 14 (1): 14109-4138

Senthilmurugan G, Vasanthe B, Suresh K. 2013. Screening and Antibacterial Activity Analysis of some Important Medicinal Plants. International Journal of Innovation and Applied Studies. 2 (2):146-152.

Shimizu K, Kondo R, Sakai K, Takeda N, Nagahata T, Oniki T. 2001. Novel Vitamin E Devirate with 4subsituted Resorcinol Moiety has Both Antioxidant and Tyrosinase Inhibitory Properties. Lipids. 36:1321-1325.

Sudarmono. 2000. Matoa (Pometia pinnataJ. R. Forst \& G. Forst) : Keragaman Jenis dan Potensi. Proseding Seminar Sehari menggali Potensi dan Meningkatkan Prospek Tanaman Hortikultura Menuju Ketahanan Pangan. Kebun Raya Bogor. LIPI.

Suedee A. 2012. Phytocemichal Studies of Mimusops elengi and Pometia pinnata Leaf Extract with Anti-HIV-1 Integrase Activity [thesis]. Songkla (TH):Prince of Songkla University.
TAPPI T264 om-88. 1988. Preparation of Wood for Chemical Analysis. in TAPPI Test Methode. Atlanta. GA : Technical Association of the Pulp and Paper Industry. 1997.

Thiel T. 1995. Science In the Real World. Microbes in Action. Department of Biology. University of Missouri. St. Louis.

Thitilertdecha N, Teerawutgulrag A, Rakariyatham N. 2010. Antioxidant and antibacterial activities of Nephelium lappaceum L. extracts. Food Science and Technology. 41:2029-2035.

Udhayasankar MR, Danya U, Punitha D, Arumugasamy K, Shalimol A. 2013. In vitro Anti-bacterial Activity of Methanolic Extract of Cardiospermum canescens - A Wild Medicinal Plant. International Journal of Herbal Medicine. 1(3):73-75.

Yuhernita, Juniarti. 2011. Analisis Senyawa Metabolit Sekunder Dari Ekstrak Metanol Daun Surian Yang Ber Potensi Sebagai Antioksidan. Makara Sains. 15(1):48-52. 